\title{
Enhancing Civic Engagement Through International Service-learning to Impact Village Community
}

\author{
Siana Halim ${ }^{1, *}$, and Juliana Anggono ${ }^{2}$ \\ ${ }^{1}$ Department of Industrial Engineering, Petra Christian University, Jalan Siwalankerto 121-131, \\ Surabaya 60236, Indonesia \\ ${ }^{2}$ Department of Mechanical Engineering and Institute for Research and Community Outreach, \\ Petra Christian University, Jalan Siwalankerto 121-131, Surabaya 60236, Indonesia
}

\begin{abstract}
Every year during semester break in July to August, Petra Christian University holds an international service-learning which is popularly known as Community Outreach Program (COP). This program has been conducted for $20 \mathrm{yr}$ since 1996 in which more than 15 university partners from 10 different countries have participated in COP. In this research the impact of COP on the community served through a survey done on 140 residents of twelve villages in Mojokerto regency, East Java province in Indonesia is studied. Cultural exchange between the villagers and the students was also measured, particularly with the overseas participants. Additionally, the economic impact and the villagers' wish for a better service that the coming COP can provide, is also investigated. The results indicate that the villagers were satisfied with the programs, either physical or non-physical programs implemented in the village during COP. The presence of the overseas students in their villages made them learn cultural, language, and religion diversities. Even though, languages were the barrier for them to communicate with the foreign students, but they treated those students as if they were their own children. The villagers hope that this program will be continued.
\end{abstract}

Key words: Community outreach program, cultural exchange, descriptive statistics, international service-learning

\section{Introduction}

Higher education institutions are inseparable parts of the community and were established to meet the wellbeing of the social, cultural and economic development of our societies. COP implementation seeks to accomplish the vision and mission of Petra Christian University (PCU) as a Higher Education Institution in applying science, technology and arts in serving others.

COP is an interdisciplinary activity set to connect the academic theories with the actual social life and development problems as a service-learning experience. As service-learning involves students in service projects by applying classroom learning to the local agencies

\footnotetext{
* Corresponding author: halim@petra.ac.id
} 
and effect positive change in the community [1], so does the COP that is located in the urban settings in East Java. Many universities also have done similar programs to COP, such as, the Utah State University, has done service-learning for motivating environmentally sustainable behavioral changes in Latino migrant agricultural families [2].

This program combines students' majors, private knowledge, experiences, and intelligences; thus discard partial view point in addressing complex social problems. They are encouraged to use broader perspective in formulating a pragmatic and effective problem-solving ability in developing the community. In carrying out the programs during COP, the students must have a good cooperation with the local community for an observation and identification of problems, selection of solutions, and their implementation as well as evaluation of the solutions. The participation of the community during COP implementation is very important since it will help the local people to recognize and solve their own problems independently in the future.

COP has been conducted for $20 \mathrm{yr}$ in which its participants come from various countries. There are more than 15 university partners from 10 different countries have participated since 1996. The total number of students who had been participated in COP up to the year of 2015 is 2434 students, consisting of 1415 overseas students and 1019 students from Petra [3]. During $20 \mathrm{yr}$ of COP, community programs have been conducted in four different regencies, namely Magetan Regency (1996 to 2003), Kediri Regency (2004 to 2013), Mojokerto Regency (2014 to present), and Kupang Regency (2013 to present) [3]. During those long years, prior to COP in a new regency, a memory of understanding (MoU) between PCU and the Regent Government is signed. Building good relationship with the local authority is also important in supporting the development of students' comprehensive thinking.

As it mentioned above that COP is an interdisciplinary and international servicelearning. As an interdisciplinary and international service-learning, the program provides transformative experiences that develop students' capacities as socially responsible global citizens [4]. This can be strongly achieved by having the students live in the family home in different villages for $3 \mathrm{wk}$ to $4 \mathrm{wk}$. They work in a group to serve the community of the village they are living in. Their activities include physical programs, such as building healthy sanitation and water filtration and non-physical program, such as teaching at elementary school. The students gain several outcomes from this program: improved academic engagement and achievement; increases in their connections to the community and the ability to make changes in the community without thinking about social status, ethnicity and religion as problems.

Research on service-learning tends to emphasize on student learning outcomes and pedagogical issues and is less attention on the community voice. To be true to the twofold responsibility of service-learning to both university and community, research must include both university and community perspectives. COP is an excellent service-learning program that students have benefited for their personal growth and development [5]. The program has been conducted for more than two decades, however the impact of COP to the community served has not been studied through a systematic survey. The purpose of this research is to explore the impact of COP through students' involvement and servicelearning programs implemented in COP. In this research, a survey was conducted in 140 residents in twelve villages. Cultural exchange occurred between the villagers and the students were measured, particularly with the students from overseas. 


\section{About COP and the villages}

\subsection{Programs in COP}

Students who are COP participants are grouped into several teams in which every nationality will have the representative in each group. Each team has around 25 members to 30 members. They experience a living lifestyle at a village in rural area alone with the communities. They learn working together in a team to implement various projects, which are selected based on their identification of the problems and needs of the community. Many projects are done by the students together with the community. In general, the programs run in COP include both physical and non-physical ones. Some of the physical programs are:

i) providing access to clean water to the society through piping and bio sand water filter programs (Figure 1(a))

ii) renovating public toilets (Figure 1(b) and Figure 1(c)) and playgroup building

iii) mural program on public facilities (Figure 1(b)).

Besides, there are several non-physical programs implemented, such as teaching preschoolers and elementary school students, as well as giving community empowerment training, introducing culture and languages from countries where the participants come from, teaching origami, and playing water rocket as part of learning outside the classroom.

\subsection{Positioning}

Place the figure as close as possible after the point where it is first referenced in the text. If there is a large number of figures and tables it might be necessary to place some before their text citation.

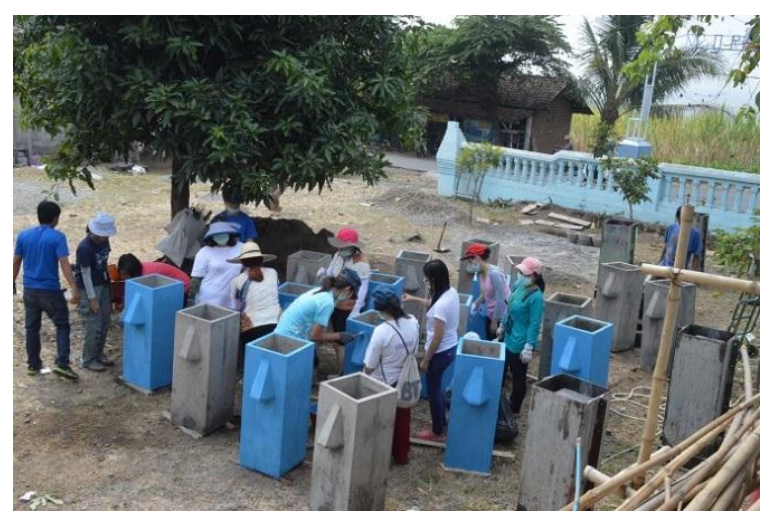

(a) 


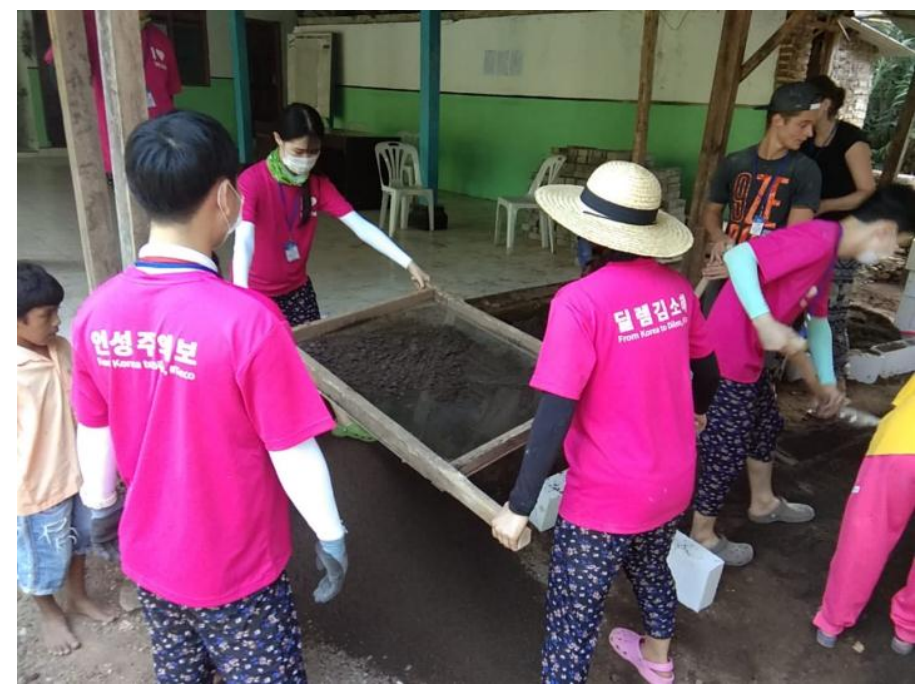

(b)

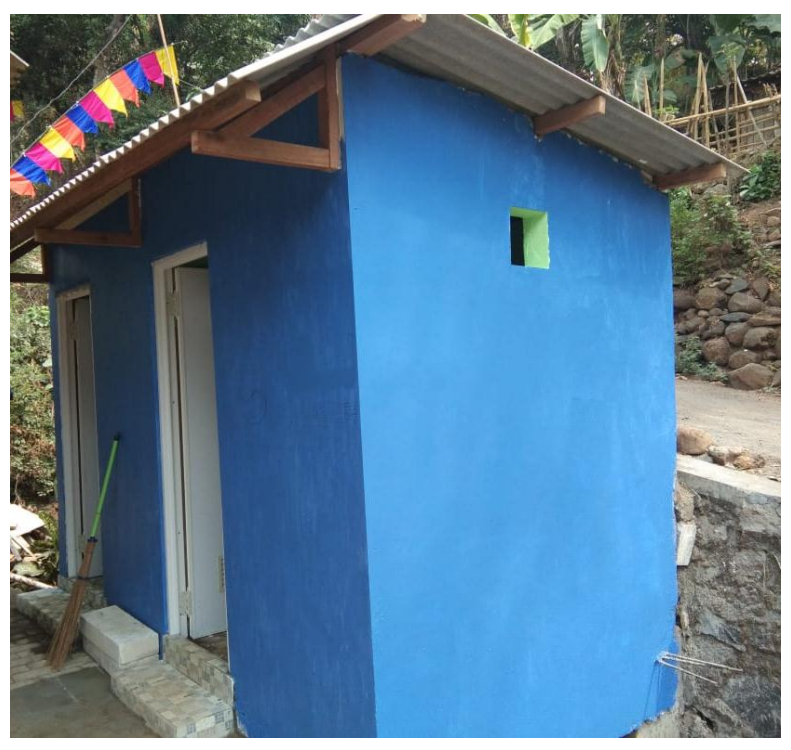

(c) 




(d)

Fig. 1. Physical programs implemented during COP (a) building bio sand water filterin Jatidukuh village, (b) renovating public toilet, (c) public toilet after renovation, and (d) mural activity in the public toilet in Gumeng village.

\subsection{Profile of the villages}

In the last 2 yr, 2015 to 2016, COP was conducted at villages and sub-villages in Mojokerto Regency. Mojokerto is a regency in East Java province. The population of the Regency was 1104522 in 2015 [6]. Mojokerto is also categorized as a small fertile area. It has big river named Brantas River. Farmers dominate the societies.

The villages that COP located were in Jatirejo and Gondang Districts. The villages where students lived were Jembul, Siman, Lebak Sari, Gumeng, Lebak, Jabung, Kulu Banyu, Nawangan, Sumber Jati, Jati, Sekuti and Gero. Most villagers work as farm workers and farmers in the field owned by a government-owned company (it is named Perhutani) which manages the forest in the area. Few of them are farmers of their own land. The yields are rice, corn, porang, coffee, and cassava. Some people are breeding goats, cows, and chickens. There are only some of them work as labors, officers, merchants and others.

Education level of majority people in those villages is low. They are elementary and junior high school graduates. To access to higher level of schooling, children have to go to the neighbouring village or district. Characteristics of the people are quite open so it is easy to communicate with them. They welcome foreigners. Therefore the village is safe and conducive for COP activities.

A lot of people in several villages prior to COP did not have access to basic sanitation. Toilets were not available in their houses but rather they went to the river nearby or the waterways or pit latrines for a lavatory. In term of the health facility, in general each village has one polyclinic in the village in which one nurse is on duty.

\section{Methodology}

To study the impact of COP on the community, a survey using a questionnaire was done on the community lives in those twelve villages mentioned above. Students who attended 
Industrial Statistics II Class helped in collecting data from the survey. They went into groups to those villages and meet the respondents (Figure 2).

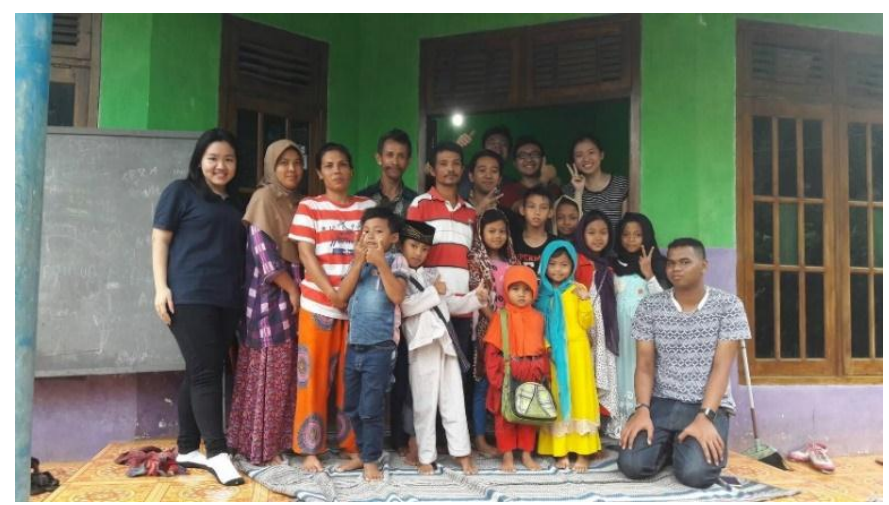

Fig. 2. Students were having a photograph with the family after the survey.

\subsection{Respondents description}

In this survey 160 villagers with the profile described in Figure 3(a), were interviewed Among them, there were 113 people (70.6\%) were above $36 \mathrm{yr}$ old and $83.7 \%$ of them reside in their villages for more than $16 \mathrm{yr}$. Most of them $(98.8 \%)$ are married and $86.2 \%$ have two or more children.

The housing condition of those villages is quite good (see Figure 3(b)), $50 \%$ of the respondents' houses are brick-walled houses, $42.5 \%$ are galvanized steel-walled houses or others. Most of the houses $(67.5 \%)$ already have ceramic tile flooring, $16.9 \%$ have concrete flooring and $15.6 \%$ have earthen flooring. Most of the houses $(66.9 \%)$ already have a toilet, and the rest (33.1\%) do not have one (see Table 1). At least $66.3 \%$ of the respondents have a motor bike.

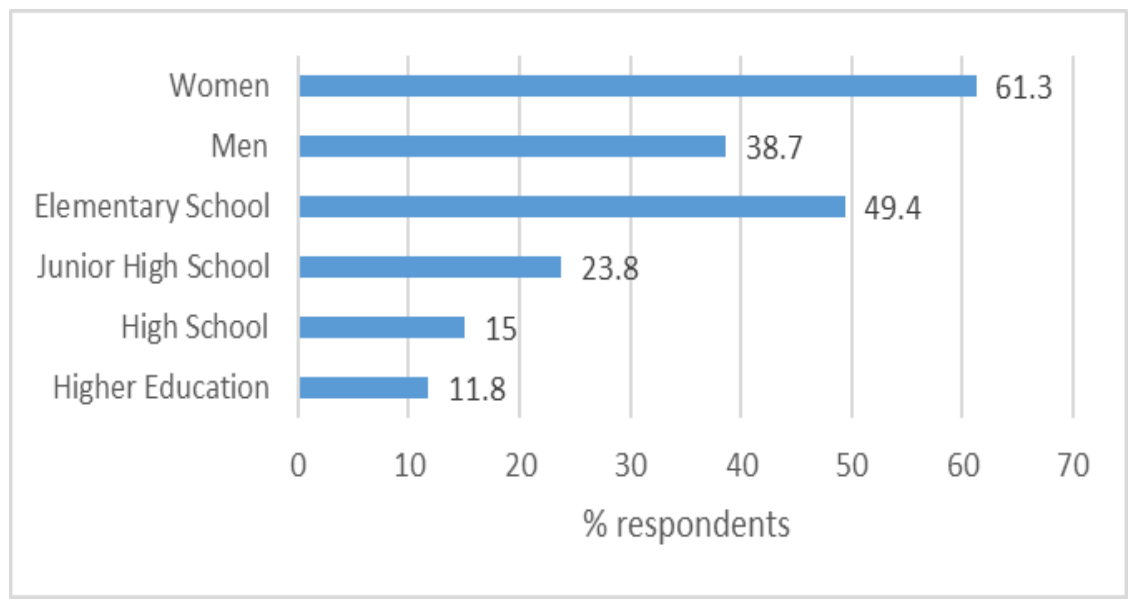

(a) 


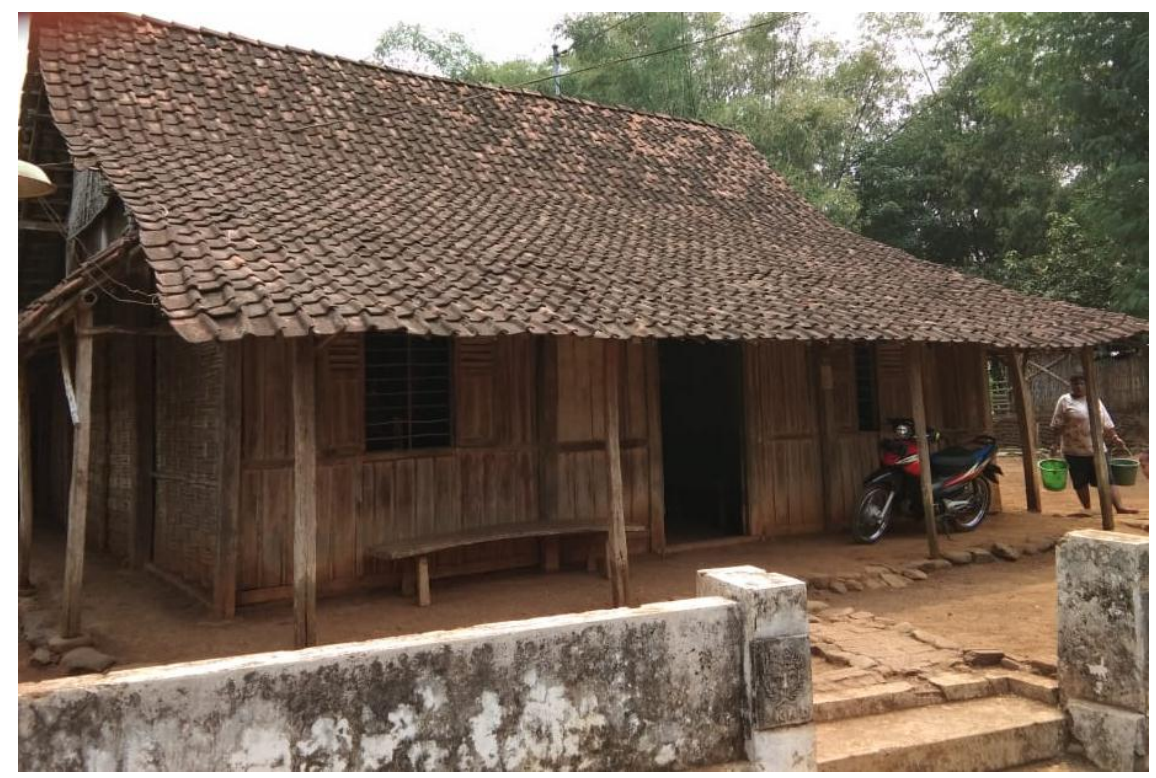

(b)

Fig. 3. (a) The profile of the respondentsand, (b) the housing condition in Jatidukuh village.

Tabel 1. Distribution of number of houses with toilet per village.

\begin{tabular}{lccc}
\hline \multirow{2}{*}{ Village } & \multicolumn{2}{c}{ Houses with a Toilet } & Total \\
\cline { 2 - 3 } & Yes & No & \\
\hline Jembul & 10 & 10 & 20 \\
Siman & 7 & 3 & 10 \\
Lebak Sari & 7 & 3 & 10 \\
Gumeng & 17 & 3 & 20 \\
Lebak & 7 & 4 & 11 \\
Jabung & 6 & 3 & 9 \\
Kulu Banyu & 13 & 7 & 20 \\
Nawangan & 9 & 11 & 20 \\
SumberJati & 5 & 3 & 8 \\
Seketi & 6 & 1 & 7 \\
Gero & 4 & 1 & 5 \\
\hline Total & 107 & 53 & 160 \\
\hline
\end{tabular}

\subsection{Design of questionnaires}

The questionnaire was designed to collect various data to study the impact of COP on the community served, the economic impact and the villagers' wish for a better service from the coming COP [7]. Additionally, the cultural exchange between the villagers and the students was also measured. Survey questions were carefully phrased to encourage target respondents in those rural area with low education level could provide accurate, unbiased and complete information. The questionnaire had open response-option questions on their participation in COP projects, the impact of COP to the wellbeing of the village. Their satisfaction about COP was also measured. At the end of the questionnaire, using openended questions, they were asked about their feedback and recommendation for the coming 
COP, such as how did they overcome the difficulties in communication with COP participants, what other problems they had besides communication, how future COP can help improve the economic life of the village.

To reach the intended respondents, the survey was conducted in the weekend when most of the respondents were home and could provide their time to complete the questionnaires.

\section{Results and discussion}

\subsection{Community involvements in the COP}

From 160 respondents, 98 of them $(61.25 \%)$ have hosted the COP participants. Three of them only hosted participants from Indonesia, 18 hosted only overseas students (no Indonesians), and 77 of them hosted mixed between Indonesian and overseas participants. They hosted as long as $4 \mathrm{wk}$ (nine respondents), $3 \mathrm{wk}$ (70 respondents), 2 wk (18 respondents), and only one respondent hosted in $1 \mathrm{wk}$. Most of them ( 85 of 98 respondents) were very welcoming and happy being hosts. There were 13 of the respondents were a bit reluctant to be a host. Communication was the biggest difficulty that they faced as a host for the overseas students, particularly when there was no Indonesian participant stayed in their house. Besides the communication, activities such as preparation of accommodation, foods, and other stuff were not a problem at all for them. This program also did not disrupt their working activities as farmers or other works.

\subsection{Satisfaction on the programs}

Most of the villagers (99\%) were very satisfied with COP. They felt the friendliness, hospitality, politeness, religion and cultural diversity from COP participants. It can be said that $100 \%$ of the villagers whom the COP participants lived and worked with were moslems. Most of them can speak Bahasa Indonesia but they speak Javanese language for their daily communication. They were so touching with the presence of participants with different religions, languages, and cultural from them. To meet these people, to these villagers, it was a new experience in their life and they found it very exciting. They were also very grateful with the teaching class provided for the children by the COP participants.

\subsection{The impact of the COP}

Besides the physical improvement of public facilities in the villages, the villagers who speak only Javanese language or Bahasa Indonesia, and never get in touch with the people outside of their community, during COP, they were in touch with the foreigners. They learned to receive other cultures and also learned to appreciate cultural diversity. Additionally, they also have learned to feel comfortable with the foreign culture, learned their languages and communicated with them. As it is stated in [8] international servicelearning is "a complex cluster of educational opportunities that include cultural competency". It helps students and in this case also the community, begin the process of moving beyond ethnocentric understanding [8]

COP has changed the life paradigm of the villagers. Now, they become aware that there are many races, cultures and religions $[9,10]$. When different races, cultures and religions are united there is a beauty emerging in diversity. The villagers and the COP participants learn to respect one another and they have found a new family through COP. 


\subsection{Feedback for the future COP}

On questions asking for feedback for future COP, the villagers suggested more improvements in particular programs as indicated in Figure 4. Most of these suggestions on those programs came from respondents from the villages of Sumber Jati, Jati, Seketi and Gero.

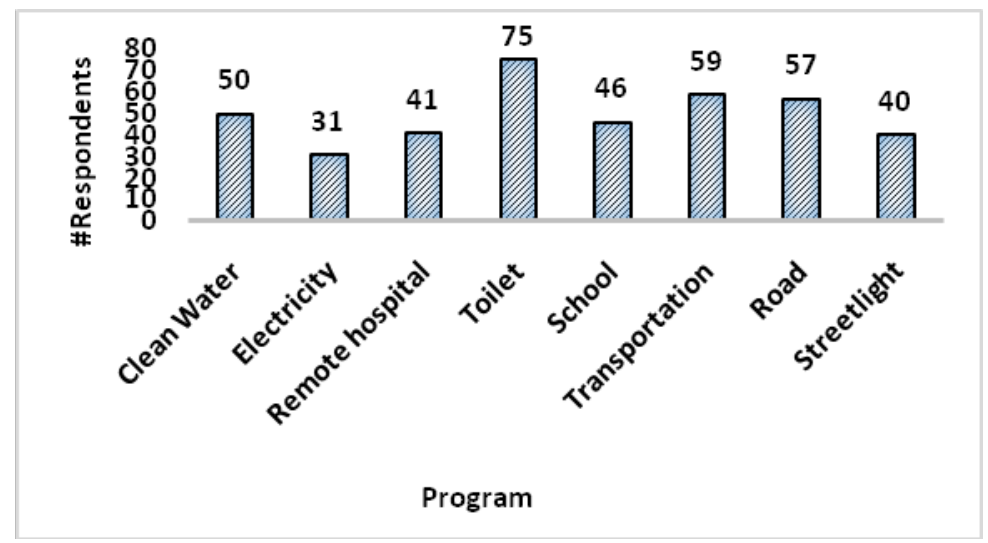

Fig. 4. Some facilities that need more improvement in the coming COP.

With regard to clean water, people in Seketi village get clean water from the dug river absorption wells. There are approximately 50 wells with the depth of up to $15 \mathrm{~m}$. The water level is low in dry season. Most of water from wells in Seketi village is turbid because it comes from river absorption. Therefore, it is hard for the people to get clean water to drink. They are usually looking for clean water in their neighborhood's wells for drinking water. When COP came to the village, bio-sand water filters were built for 25 families to enable them to get the clean water. COP had limited time and fund therefore it could not build more water filters for remaining families to access clean water.

Comments on school and road dominantly came from respondents from Nawangan $(75 \%)$ who stated that it was difficult to access the school, since the school location is far from their village as the transportation to reach there is also difficult and the road condition is not good (see Figure 5(a)). 




(a)

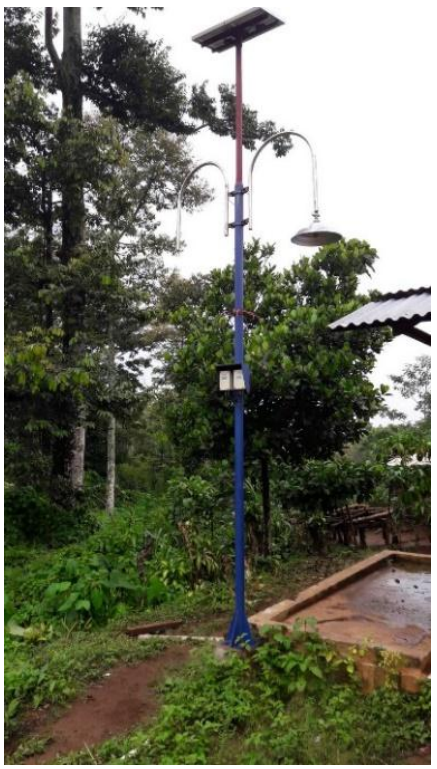

(b)

Fig. 5. (a) Narrow and bad road condition at Nawangan village and (b) solar cell installed in one communal toilet in Nawangan village.

All the facilities which were built during COP are still working well and they take good careand use them daily. However, there are some of the facilities built during the COP are currently broken, i.e. the solar cell lighting. (Figure 5(b)). They hope that the COP can be better and better in the future with more participants will come to join and they will stay longer in their village. Moreover, they also expect that every household in the village can have experience to be a host parent for COP participants. Besides, they wishthat the participants can be more engaged with the host and will not only be occupied with the program they have to complete.

In regard with other facility, they expect more public toilets and bathrooms can be built, as well as mosque repairment, and some programs are run for schools and women.

\section{Conclusions and recommendation}

The COP was very fruitful to the villagers. They were very satisfied with the program, either from physical or non-physical programs. Piping and water purification projects helped them to access clean water.

The presence of the overseas students in the villages has changed their perspective in seeing a world outside their daily routine activities in the village; a world with its diversity in culture, languages, and religions. In term of relationships developed during COP, most of the villagers regarded the COP participants as their own children. Through COP they built kinship and togetherness although languages were the barrier among them to communicate. To overcome this communication, they suggested that at least one Indonesian participant should stay in the house as companion to the overseas participants; or every COP participant is trained to be able to speak daily Bahasa Indonesia. For the villagers who only speak Javanese language, the COP helped them improve their ability in speaking Bahasa Indonesia. 
The authors were very grateful to the 2016 Industrial Statistics Class who helped conduct the survey in villages in Mojokerto District. The assistance from Mr. Frans Limbong and Mr. Poedi S. Wartono from Institute for Research and Community Outreach of Petra Christian University to the students during the survey was greatly appreciated. The research fund provided by the same Institute has been a great help in making this study possible.

\section{References}

1. C. Levesque-Bristol, T.D. Knapp, B.J. Fisher. Journal of Experiential Education, 33, 3:208-224 (2010). http://journals.sagepub.com/doi/10.1177/105382590113300302

2. J.I. Thomson, R.G.H. Brain. Journal of Service-Learning in Higher Education, 6:2132(2017). http://journals.sfu.ca/jslhe/index.php/jslhe/article/view/114

3. F. Lesmana, Y.B. Cahyono. COP misi yang tak putus aksi yang tak pupus [COP: unstoppable mission, unbreakable action]. Surabaya: Petra Press (2016). p. 9.

4. S. Fry, A. Hale, K. Soll, C. Bower, A. Jaffari. International Service-Learning, Partnerships: A Journal of Service-Learning and Civic Engagement, 8, 1:16-27(2017). http://libjournal.uncg.edu/prt/article/view/1294

5. J. Anggono, Y.B. Cahyono, N.P., Adhi, F. Pasila. International service-learning through community outreach program in villages in kediri-east java: a study on students' reflection journals. Service-Learning Studies Series No. 4 (ICU ServiceLearning Centre, Japan, 2009).

https://www.researchgate.net/publication/43649723_International_Service-

Learning through_Community_Outreach Program in Villages in KediriEast Java_A_Study on_Students'_Reflection_Journals_in_Lessons from_ServiceLearning in Asia Results_of_Collabora

6. Dinas Komunikasi dan Informatika Kabupaten Mojokerto. Kependudukan [Online] from http://mojokertokab.go.id/thm/v1/?vi=data\&mode=1 (2017). [Accessed on 29 June 2017].

7. C. Marshall, G.B. Rossman. Designing qualitative research. 6th ed. USA: Sage Publications, Inc (2016). pp. 141-178 https://uk.sagepub.com/en-gb/asi/designingqualitative-research/book240236

8. S.Y. Nickols, N.J., Rothenberg, L. Moshi, M. Tetloff. Journal ofHigher Education Outreach and Engagement, 17, 4:97-124 (2013). https://files.eric.ed.gov/fulltext/EJ1018797.pdf.

9. A.E., Green. College Composition and Communication, 55, 2:276-301 (2003). https://eric.ed.gov/?id=EJ841118

10. T.B. Smith, M.D. Rodríguez, G. Bernal. Journal of Clinical Psychology, 67:166175(2011).) https://onlinelibrary.wiley.com/doi/full/10.1002/jclp.20757 